\title{
II - 2-5 高齢者における胸腰椎圧迫骨折の予後と造影MRIとの関連について
}

宮崎社会保険病院 整形外科 ${ }^{1}$ 、宮崎医科大学 整形外科 ${ }^{2}$

○益山 松三（ますやましょうぞう） 1 、田辺 龍樹 ${ }^{1} 、$

松元 征徳 ${ }^{1}$ 、山口 政一朗 ${ }^{1}$ 、田島 直也 ${ }^{2}$ 、矢野 浩明 ${ }^{2}$

【目的】胸腰椎圧迫骨折患者の予後と経時的X線変化および造影MRIとの関連につき検討す る。【対象ならびに方法】1998年より1999年の間に当院にて入院加療、MRI検査を行った胸腰 椎圧迫骨折患者33例中、造影MRIを施行した 8 症例を対象とした。同時に経時的X線検査と疼 痛の状態を検討した。入院 2 ケ月後、疼痛の残存しない者を予後良好例、残存する者を不良例 とした。【結果】予後良好例では全椎体で造影陰性を認めず、不良例では 7 椎体のうち 4 椎体 で造影陰性を認め、これらは全てX線学的にも圧潰の増悪を認めた。【考察】予後不良例で高 率に認められた造影MRIにおける非造影部の出現は同部の血流量減少が示唆され、容易に椎体 圧潰が進行したことより予後不良となる原因の一つとして推察される。

\section{II - 2-6 上位腰椎椎間板へルニアの検討}

熊本中央病院 整形外科

○藤井 洋（ふじい ひろし）、岡嶋 啓一郎、高野 晴夫、 堤 隆治、西 芳徳、渡辺 弘之

【目的】腰部椎間板ヘルニアのうち、上位椎間板へルニア（L 3／4 以上）の報告例は $3 \%$ 以 下と少ない。今回、我々は過去 12 年間に 42 例の上位椎間板へルニアの症例を経験したので、若 干の文献的考察をふまえて、報告する。【方法】1988年より1999年まで12年間に当院で手術し た、42例について調べた。平均年令は、40.9才であった。男性 34 人、女性 8 人、後方へルニア 摘出術31例、前方固定11例。【結果】患者の $81 \%$ に肥満がみられ、腰痛を主訴とする例 $(62 \%)$ が多かった。なんらかのきっかけにより、腰痛を主とする症状が増強した例が多かった。下位 腰部椎間板ヘルニア、脊柱管狭窄症、腰椎変性过り症、側彎、後彎等の脊椎合併症が多く（71 \%）に認められ、また膀胱直腸障害の合併率も25\%に認められた。ほとんどの症例で手術後の 症状は改善傾向を認めた。 


\title{
II $-2-7$ 第 5 腰椎分離症に腰椎椎間板ヘルニアを合併した症例の検討
}

国立病院九州医療センター 整形外科

○辰元 要仁（たつもととしひと）、寺田 和正、前田 剛、 宮崎 清、中山 功一、濱田 貴広、宮原 寿明

第 5 腰椎分離症に腰椎椎間板へルニアを合併した 3 症例を経験した。各症例の臨床経過と術式 選択について検討した。【症例 1】33才女性。L $5 / \mathrm{S} 1$ 外側ヘルニアによるL 5 神経根障害。 分離部の骨軟骨性椎間孔狭窄 (一)。片側骨形成的椎弓切除術施行し、ヘルニア摘出術後、ス クリューを用いた分離部固定施行。【症例 2】27才男性。L $5 / \mathrm{S} 1$ ヘルニアによるS 1 神経根 障害。椎間孔狭窄 (一)。L 5 / S 1 laminotomy後、ヘルニア摘出術およびペディクルスクリュ 一とフックを用いた分離部固定施行。【症例 3】50才男性。L $4 / 5$ ヘルニアと椎間孔狭窄に よるL 5 神経根障害。ヘルニア摘出術、分離椎弓切除術後TSRHを用いたL $4 \sim \mathrm{S} 1$ 後側方固定 施行。【考察】分離症にヘルニアを合併した場合、神経根障害のレベルと部位、椎間孔狭窄の 有無、椎間不安定性の有無等を十分評価して、各症例に応じた術式選択が重要である。

\section{II - 2-8 腰椎椎間板ヘルニア再手術例の検討}

\author{
長崎三菱病院 整形外科 \\ ○山本 尚幸（やまもと たかゆき）、瀬良 敬祐、中村 昌一、 \\ 坂本 和隆
}

【目的】いわゆるMOBの原因は様々であるが、その中の一つに再発へルニアがある。今回我々 は再手術に至った原因を探るため、再発の様態、術後成績等について検討したので報告する。

【対象】1978年から1999年までに当院にて腰椎椎間板へルニアと診断され、Love法のみを施 行した697例のうち再手術を行った30例（男性25例、女性 5 例）である。全例、初回および再 手術とも当院で行った例とした。初回手術時年齢は19７0歳 (平均33.5歳)であった。【結果】 再発率は $4.3 \%$ であた。再発までの期間は 1 力月〜 16年 4 力月（平均 4 年 11 力月）であり、 初回手術部位はL 3 /4 1 例、L 4 / 5 13例、L $5 /$ S 1 16例であった。再発部位は同一椎間 板同側18例、同一椎間板反対側 6 例、他椎間板 5 例であった。再手術方法はLove法単独例 14 例、Love法+PLF例 7 例、Love法+PLF+instrument例 8 例、前方固定術 1 例であった。 


\title{
II $-2-9$ 腰椎椎間板へルニアの頭尾例進展例のX線学的检討
}

福岡市民病院 整形外科

○鍋山 亮太郎（なべやまりょうたろう）、黒瀬 眞之輔、 小山 正信、甲斐 之尋、稲留 辰郎、楊 昌樹

【目的】腰椎椎間板へルニアはしばしば頭尾側方向への進展形態をとる。今回我々はX線で上 位椎体の矢状方向の可動性とMRIでのヘルニアの進展形態、椎間関節角との関係を調べた。

【対象】H11年 4 月からH12年 1 月までに腰痛または下肢痛を主訴にMRIを撮影した60歳以下 の患者で、L $4 / 5$ またはL $5 / \mathrm{S} 1$ 腰椎椎間板へルニアと診断された症例。（変性すべり症、 脊柱管狭窄症、再発へルニアは除外）【結果】L 4 / 5 で168例中26例に尾側への進展、L 5 ／ S 1 で147例中 3 例に頭側への進展、10例に尾側への進展を認めた。へルニアが移動する症例 の約半数は上位椎体が後方にずれていた。【考察】MRIでのヘルニアの進展と椎間関節角、動 態X線での上位椎体の矢状方向の可動性との関係について検討し、若干の考察を加えて報告す る。

\section{$\mathbb{I}-2-10 \quad$ 腰椎椎間板へルニアにおける神経根血流变化の检討}

\author{
福岡大学 整形外科 \\ ○檜田 伸一 (ひだ しんいち)、内藤 正俊、蒲原 光義、 \\ 吉村 豊暢
}

【目的】腰椎椎間板へルニアにおける根性疼痛発生の詳細なメカニズムについては、未だ統一 した見解はない。今回我々は、神経根血流の術中変化について検討したので若干の考察を加え て報告する。【対象及び方法】対象は腰椎椎間板ヘルニアの診断にて手術を施行した 7 例で、 平均年齢は34.1才であった。神経根血流の測定にはAdvance社製非接触型レーザー血流計を用 い、ヘルニア塊により圧迫された神経根の末梢側の血流量、血液量、血流速度を計測し除圧前 後の值を比較した。【結果】ヘルニア摘出前の神経根血流量は6.63土1.63、血液量は526.7 41.8、血流速度は $0.84 \pm 0.25$ でった。除圧後の神経根血流量は $11.4 \pm 2.1$ 、血液量は $563.8 \pm$ 69.5、血流速度は $4.3 \pm 2.2 て ゙$ 有意に血液循環は改善していた。【考察】腰椎椎間板ヘルニアに おける神経根の血流障害は疼痛の発生に関与している事が示唆された。 